The flycatcher was not seen again until about one week later when the Handysides observed it in a pasture about 0.5 mi. east of the farm house; this was the last recorded sighting.

Twelve other Manitoba records of Scissor-tailed Flycatchers exist for the period 1880 to October 1953. ${ }^{2}$ More recent sightings include the following: an immature bird 18 August 1979 by Peter Taylor, $13 \mathrm{~km}$ northwest of Whitemouth, Manitoba; one 26 May 1980 by Sharon Howe at Pinawa, Manitoba; one 5 June 1982 by Dennis Fast north of Oak Hammock Marsh; and one 11 May 1985 by the Gordon Grieef family at Grand Beach Provincial Park
(P. Taylor and H. Copland, comm.). ${ }^{34}$

HATCH, DAVID 1982. Chick Notes. Winnipeg Free Press, $30 \mathrm{Ju}$

2 LAWRENCE, A.G. n.d. Chick Notes. Winnipeg Free Press (sup from records of Herb Copland, Man Museum of Man and Nature).

'TAYLOR, PETER 1979. Scissor-t Flycatcher near Whitemouth, Mani Blue Jay 37(4):228.

4 TAYLOR, PETER 1984. Wings a the Winnipeg. Manitoba Natur Society, Eco Series No. 2

\section{UNUSUAL VARIATIONS IN PLUMAGE OF THE HOUSE SPARROW}

\section{WILLIAM A. S. SARJEANT,} Department of Geological Sciences, University of Saskatchewan, Saskatoon, Saskatchewan. S7N OWO

Since its deliberate introduction into North America during the 19th century, the (originally) European House Sparrow has not only spread widely -- more widely, indeed, than many of us would wish -- but also shown so rapid a degree of plumage variation that at least one, perhaps several North American subspecies may already be recognized.

Many individual variations have been reported, including albinistic and melanistic individuals. To the list of variations I should like to add two more, both among the mob of birds on the University of Saskatchewan campus during late March and early April and both males.

The cap of the male House Sparr normally grey. In one individual, ever, the colour of th whole foreh crown and nape was blue, almc cerulean blue. Otherwise his plur was standard.

The secord differed from the pattern in a very odd fashion. It $w$ if a line of colour demarcation had drawn across the back, just below not at) the base of the mantle. whole middle and lower part o back and the rump were of a very fawn colour. The tail, however, quite normal.

I should stress that both birds seen repeatedly, always in the are tween the Thorvaldson Building an Murray Memorial Library. When mob of sparrows of which they w part left the campus, they departed 